\title{
THE KARYOTYPE OF Alstroemeria diluta EHR. BAYER SUBSP. chrysantha (ALSTROEMERIACEAE)
}

\author{
Carlos M. Baeza ${ }^{1 *}$, Eduardo Ruiz ${ }^{1}$, Patricio Novoa ${ }^{2}$
}

\begin{abstract}
The karyotype of Alstroemeria diluta subsp. chrysantha Ehr. Bayer from Chile was examined. The species has $2 n=2 x=16$ chromosomes, with $4 \mathrm{~m}+4 \mathrm{sm}+2 \mathrm{st}$-sat $+4 \mathrm{t}+2 \mathrm{t}$-sat. The reported karyotype is very asymmetrical (AsK $\%=71.4$ and Syi $=40.0 \%$ ). This karyotype is similar to that published previously for Alstroemeria graminea Phil.
\end{abstract}

Key words: Alstroemeria, karyotype, ornamental plant, Chile.

\section{INTRODUCTION}

In Chile there exist approximately 44 genera and 180 species of geophytes that have ornamental value, only being surpassed in number by attractive species in the flora of South Africa (Peñailillo, 2000). Among the species in Chile, almost $90 \%$ are endemic (Benoit, 1989), and they are especially concentrated in the families Alliaceae, Alstroemeriaceae, Amaryllidaceae, and Tecophilaceae.

Alstroemeria L. (Alstroemeriaceae) is an American monocot genus with about 50 species distributed principally in Chile and Brazil (Bayer, 1987; Muñoz and Moreira, 2003).

In Chile the genus contains 49 taxa, of which 40 are endemic (Muñoz and Moreira, 2003), primarily found in the Mediterranean region of the country. This region harbors about $47 \%$ of the total plant species found in Chile (Myers et al., 2000), and many of these taxa have serious conservation difficulties due to small population sizes and recent impacts from human activities.

There exist a large number of Chilean species of Alstroemeria that are cultivated for ornamental use throughout the world, among these being A. aurea Graham, A. pelegrina L., A. ligtu L. and A. magnifica Herb. (Baeza et al., 2008). In this context, A. diluta Ehr. Bayer is an endemic species that has great cultivation potential, especially in view of its beautiful flowers (Figure 1AC), plus the fact that seeds are available commercially (Chileflora, 2010). This species is found from Carrizal

\footnotetext{
${ }^{1}$ Universidad de Concepción, Facultad de Ciencias Naturales y Oceanográficas, Casilla 160-C, Concepción, Chile. *Corresponding author (cbaeza@udec.cl).

${ }^{2}$ Jardín Botánico Nacional, Camino el Olivar 305, El Salto, Viña del Mar, Chile.

Received: 25 May 2010.

Accepted: 22 September 2010.
}

Bajo (280' S lat) in the Atacama Region, to Punta Curaumilla ( $33^{\circ} 05^{\prime} \mathrm{S}$ lat) in the Province of Valparaiso. It is characterized by having a small height (no taller than 15 $\mathrm{cm}$ ), with outer tepals pink or yellowish and denticulate at the margin, and with internal tepals purple. It grows on old marine terraces with abundant large limestone gravel, but here being somewhat weak and poorly developed. It also grows more successfully on interior low hills that correspond to ancient Pliocene terraces (Paskoff, 1967). With regard to vegetation, this species is an important component of the coastal sclerophyllous forest, growing preferentially in degraded areas, and co-occurring with annual grasses in open prairies that are occasionally impacted by forest fires (Peralta, 1972).

This scientific note documents the karyotype of Alstroemeria diluta subsp. chrysantha Ehr. Bayer, including a comparison with A. graminea Phil., with which it shares many karyotypic similarities.

\section{MATERIALS AND METHODS}

Two populations of Alstroemeria diluta subsp. chrysantha were studied from Chile: (1) Región de Valparaíso, Provincia de Valparaíso, Punta Curaumilla, camping Las Gaviotas, 58 m.a.s.1. ( $33^{\circ} 05^{\prime}$ S, $71^{\circ} 43^{\prime}$ W), 11 December 2007, C. Baeza 4264 (CONC); (2) Jardín Botánico Nacional, Lote C, 71 m.a.s.l. ( $33^{\circ} 02^{\prime}$ S, $71^{\circ} 29^{\prime}$ W), 24 December 2007, P. Novoa s.n. (Herbario Jardín Botánico Nacional, Viña del Mar, Chile).

Study of the chromosomes, measurement, and construction of karyotypes, were done following methods described by Baeza et al. (2006). Root tips were obtained from plants cultivated in the greenhouse. For each population, five individual plants were examined (with 10 clear metaphase plates observed from each individual). The index of karyotypic asymmetry (AsK \%) as defined 

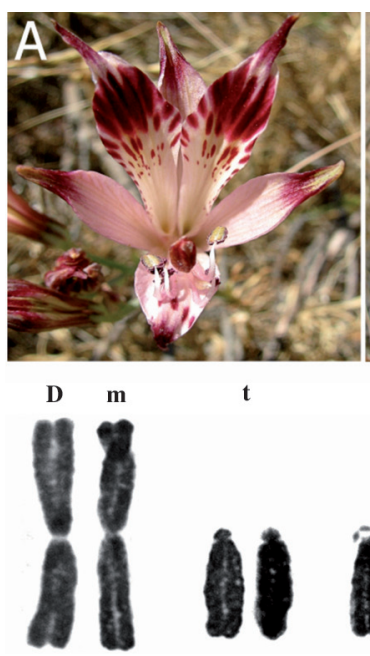

$\mathbf{t}$

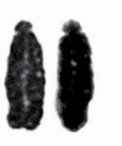

2

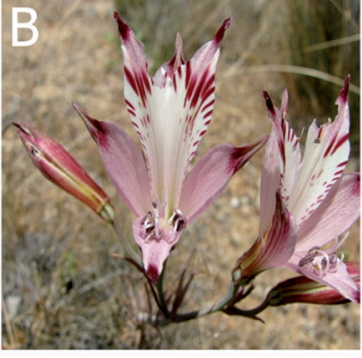

st

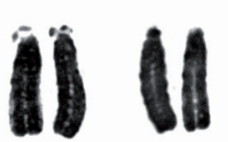

3

$\mathbf{t}$

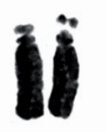

5

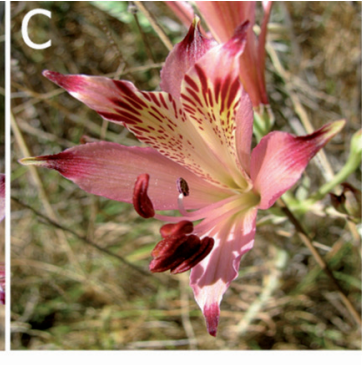

m

m

sm

Figure 1. A-C. Photographs of Alstroemeria diluta subsp. chrysantha. D: Karyotype of Alstroemeria diluta subsp. chrysantha. Scale $=5 \mu \mathrm{m}$.

by Arano and Saito (1980), the Syi: asymmetry index of Venora et al. (2002), and the total diploid length of the chromosomes (LTC, $\mu \mathrm{m}$ ) were used. The chromosomes were classified following Levan et al. (1964).

\section{RESULTS AND DISCUSSION}

Alstroemeria diluta subsp. chrysantha has $2 n=2 x=16$ chromosomes, with an asymmetrical karyotype and a haploid chromosome complement of $2 \mathrm{~m}+2 \mathrm{sm}+1$ st-sat $+2 t+1 t$-sat, i.e., 2 pairs of metacentric chromosomes (pairs 1 and 7), 2 pairs of submetacentrics (pairs 6 and 8), 1 pair of subtelocentric chromosomes with a satellite (pair 5), and 3 pairs of acrocentrics (pairs 2-4, with pair 3 containing a satellite) (Figure 1D, Table 1). The index of karyotypic asymmetry of Arano and Saito (AsK \%) was 71.4, the Syi 40.0\%, and the LTC $119.6 \mu \mathrm{m}$.
Alstroemeria diluta subsp. chrysantha has the most asymmetric karyotype and the lowest value of LTC known so far among all the perennial species of Alstroemeria. It is comparable only to the karyotype of the sole annual species in the genus, A. graminea, which has an even lower value of LTC and an even more asymmetrical karyotype $(\mathrm{LTC}=10.8 \mu \mathrm{m} ;$ AsK $\%=80.1 \%$; Sy I $=24.8 \%$; JaraSeguel et al., 2004). Both species share very asymmetrical karyotypes, low values of LTC, and presence of only one pair of large metacentric chromosomes (pair 1).

Considering the distinctive cytological features and the beauty of the flowers of this species, it may well have excellent potential as an ornamental plant for gardens, terrace pots, or as cut flowers for the local, national, or international horticultural trade. In the past decade, this latter activity has become very important for the economy of Chile. In 2008, the total export value of cut flowers

Table 1. Chromosomes measurements of Alstroemeria diluta subsp. chrysantha. Average length of chromosomes calculated in percent of the mean diploid genome length.

\begin{tabular}{|c|c|c|c|c|c|c|}
\hline $\begin{array}{l}\text { Chromosome } \\
\text { pair }\end{array}$ & Arm length & $\begin{array}{c}\text { Short arm } \\
\text { length }\end{array}$ & $\begin{array}{c}\text { Relative } \\
\text { total length }\end{array}$ & $\begin{array}{c}\text { Absolute } \\
\text { total length }\end{array}$ & Products & $\begin{array}{c}\text { Chromosome } \\
\text { type }\end{array}$ \\
\hline & \multicolumn{2}{|c|}{$(\%) \pm \mathrm{SD}$} & $\%$ & \multicolumn{2}{|c|}{$\mu \mathrm{m}$} & \\
\hline 1 & $6.92 \pm 0.10$ & $6.49 \pm 0.16$ & 13.41 & 16.00 & 1.07 & $\mathrm{~m}$ \\
\hline 2 & $5.86 \pm 0.16$ & $0.58 \pm 0.18$ & 6.44 & 7.68 & 10.10 & $\mathrm{t}$ \\
\hline 3 & $5.60 \pm 0.20$ & $0.80 \pm 0.12$ & 6.40 & 7.64 & 7.00 & t-sat \\
\hline 4 & $5.72 \pm 0.15$ & $0.43 \pm 0.10$ & 6.15 & 7.34 & 13.30 & $\mathrm{t}$ \\
\hline 5 & $4.63 \pm 0.10$ & $1.06 \pm 0.12$ & 5.69 & 6.79 & 4.37 & st-sat \\
\hline 6 & $3.10 \pm 0.12$ & $1.58 \pm 0.14$ & 4.68 & 5.58 & 1.96 & $\mathrm{sm}$ \\
\hline 7 & $2.07 \pm 0.14$ & $1.75 \pm 0.18$ & 3.82 & 4.56 & 1.18 & $\mathrm{~m}$ \\
\hline 8 & $2.22 \pm 0.20$ & $1.30 \pm 0.16$ & 3.52 & 4.20 & 1.71 & sm \\
\hline
\end{tabular}

SD: standard deviation; R: brachial index; m: metacentric; sm: submetacentric; st: subtelocentric; st-sat: subtelocentric with satellite; t: telocentric; t-sat: telocentric with satellite. 
surpassed US\$3.3 million (FOB), with The Netherlands and the United States being the principal international markets (Reyes and Barrera, 2009).

Cytological characterization of a plant species with ornamental potential constitutes a valuable contribution toward protecting this biological resource, especially considering ongoing intensive searches for new genotypes of ornamental importance. Many European countries utilize Chilean species in programs for genetic improvement, but if the basic cytological information is not available, further development can be hindered. From a more national perspective, lack of biological information may lead to a neglect of this species as a valuable part of Chile's natural heritage, perhaps resulting in missed opportunities for successful revenue-sharing.

\section{CONCLUSIONS}

Alstroemeria diluta subsp. chrysantha is a perennial species of the genus that shows the most asymmetrical karyotype so far investigated. It is similar, however, to that of Alstroemeria graminea, the only annual species of the genus.

\section{ACKNOWLEDGEMENTS}

We greatly appreciate: financial support from project FONDECYT 1070520; and use of laboratory facilities from the Departamento de Botánica of the Universidad de Concepción. Also to Tod Stuessy for translating the manuscript into English.

\section{RESUMEN}

Karyotype of Alstroemeria diluta Ehr. Bayer subsp. chrysantha (Alstroemeriaceae). Alstroemeria diluta subsp. chrysantha Ehr. Bayer (Alstroemeriaceae) fue examinada citológicamente. Esta especie presenta un número cromosómico somático de $2 \mathrm{n}=2 \mathrm{x}=16$ cromosomas, con una fórmula haploide constituida por $4 \mathrm{~m}+4 \mathrm{sm}+2 \mathrm{st}-\mathrm{sat}+4 \mathrm{t}+2 \mathrm{t}$-sat cromosomas. El cariotipo es muy asimétrico, con valores de AsK $\%=71,4$ y Syi $=40,0 \%$. Estos resultados se compararon con los de Alstroemeria graminea Phil., especie que presenta un cariotipo muy similar.

Palabras clave: Alstroemeria, cariotipo, planta ornamental, Chile.

\section{LITERATURE CITED}

Arano, H., and H. Saito. 1980. Cytological studies in family Umbelliferae 5. Karyotypes of seven species in subtribe Seselinae. La Kromosomo 2:471-480.
Baeza, M., O. Schrader, E. Ruiz, and M. Negritto. 2006. Análisis comparativo del cariotipo en poblaciones de Alstroemeria ligtu subsp. ligtu y A. ligtu subsp. simsii (Alstroemeriaceae) de Chile. Darwiniana 44(2):313318.

Baeza, C., O. Schrader, E. Ruiz, and M. Negritto. 2008. Alstroemeria presliana Herb. (Alstroemeriaceae) in Chile from a cytogenetic perspective. Chilean Journal of Agricultural Research 68:328-333.

Bayer, E. 1987. Die Gattung Alstroemeria in Chile. Mitteilungen der Botanischen Staatssammlung München 24:1-362.

Benoit, I. 1989. Libro rojo de la flora terrestre de Chile. 157 p. Corporación Nacional Forestal. Impresora Creces, Santiago, Chile.

Chileflora. 2010. Alstroemeria diluta ssp. chrysantha. Available at www.chileflora.com/Florachilena/ FloraEnglish/HighResPages/EH1230.htm. (accessed March 2020).

Jara-Seguel, P., C. Palma-Rojas, and E. Brand. 2004. Karyotype and C-bands in the annual Inca Lily Alstroemeria graminea. Belgian Journal of Botany 137(2):199-204.

Levan,A., K. Fredga, andA. Sandberg. 1964. Nomenclature for centromeric position on chromosomes. Hereditas 52:201-220.

Muñoz, M., and A. Moreira. 2003. Alstroemerias de Chile. Diversidad, distribución y conservación. 140 p. Taller La Era, Santiago, Chile.

Myers, N., R. Mittermeier, C. Mittermeier, G. Fonseca, and J. Kent. 2000. Biodiversity hotspots for conservation priorities. Nature 403:853-858.

Paskoff, R. 1967. Antecedentes generales sobre la evolución del litoral de Chile del Norte durante el Plioceno y el Cuaternario. Boletín Sociedad de Geógrafos Chile 3:3-4.

Peñailillo, P. 2000. Introducción a las geófitas chilenas de valor comercial. In Peñailillo, P., and F. Schiappacasse (eds.) Seminario Los geófitos nativos y su importancia en la floricultura. Fundación para la Innovación Agraria (FIA):1-10. Dirección de Investigación Universidad de Talca (DIUT), Talca, Chile.

Peralta, M. 1972. Curso de conservación, uso y clasificación de suelos. 301 p. Universidad de Chile, Facultad de Ciencias Forestales, Santiago, Chile.

Reyes, M., and D. Barrera. 2009. Las flores de corte chilenas en 2007 y 2008. Oficina de Estudios y Políticas Agrarias (ODEPA), Santiago, Chile.

Venora, G., S. Blangiforti, M. Ruffini Castiglioni, D. Pignone, F. Losavio, and R. Cremonini. 2002. Chromatin organisation and computer arded karyotyping of Triticum durum Desf. cv Timilia. Caryologia 55:91-98. 